\title{
Thermothrix azorensis sp. nov., an Obligately Chemolithoautotrophic, Sulfur-Oxidizing, Thermophilic Bacterium $\dagger$
}

\author{
ELENA V. ODINTSOVA, ${ }^{1}+$ HOLGER W. JANNASCH, ${ }^{1 *} \mathrm{~J}^{\prime}$ ANTHONY MAMONE, ${ }^{2}$ \\ AND THOMAS A. LANGWORTHY ${ }^{3}$ \\ Woods Hole Oceanographic Institution, Woods Hole, Massachusetts 02543, ${ }^{1}$ U.S. Biochemical Corporation, \\ Cleveland, Ohio $44128,^{2}$ and University of South Dakota, Vermillion, South Dakota $57069^{3}$
}

\begin{abstract}
A new aerobic, obligately chemolithoautotrophic, thermophilic, sulfur-oxidizing bacterium, Thermothrix azorensis, was isolated from a hot spring on Sao Miguel Island in the Azores. The cells of this organism are gram negative, nonsporulating, and rod shaped. Filament formation appears to occur as a response to nonoptimal growth conditions. Growth occurs at 63 to $86^{\circ} \mathrm{C}$, and the optimum temperature is 76 to $78^{\circ} \mathrm{C}$. The optimum pH range for growth is 7.0 to 7.5 . The $\mathrm{G}+\mathrm{C}$ content of the DNA of our isolate is $39.7 \mathrm{~mol} \%$. This isolate uses thiosulfate, tetrathionate, hydrogen sulfide, and elemental sulfur as energy sources. Of particular interest are the absence of Calvin cycle enzymes and the initial appearance of sulfide during the lag phase of growth of aerobic cultures grown on elemental sulfur. The subsequent formation of thiosulfate is followed by oxidation of the thiosulfate to sulfate. $T$. azorensis differs from the only other Thermothrix species that has been described, Thermothrix thiopara, by having higher optimum and maximum growth temperatures, by being an obligate chemolithoautotroph, and by its close but separate position on a 16S rRNA sequence-based phylogenetic tree. Our $T$. azorensis isolate has been deposited in the American Type Culture Collection as strain ATCC $51754^{\mathrm{T}}(\mathrm{T}=$ type strain $)$.
\end{abstract}

Most geothermal environments are rich in reduced sulfur compounds and provide suitable habitats for various groups of sulfur-oxidizing bacteria. However, in hydrothermal springs, growth of aerobic microorganisms is limited by the low solubility of oxygen at high temperatures. Other limitations may be imposed by competition with abiotic oxidations of sulfur compounds or intermediate metabolites. Facultatively or obligately aerobic sulfur oxidizers that grow at temperatures up to $90^{\circ} \mathrm{C}$ have been found to belong primarily to the archaeal domain $(47,54)$, particularly to the genera Sulfolobus, Acidianus, and Desulfurolobus.

According to Aragno (2), the thermophilic, aerobic, sulfuroxidizing bacteria can be divided into three categories: hydrogen-oxidizing bacteria which are also able to oxidize reduced sulfur compounds $(1,4,10)$ or require them $(44)$, strictly thermophilic sulfur oxidizers belonging to the genus Thermothrix (16), and moderately thermophilic thiobacilli $(15,21,32,51$, 53). So far, Thermothrix thiopara (16) is the only validly described, thermophilic, sulfur-oxidizing (eu)bacterium. A phylogenetic analysis of this organism is included in this paper. $T$. thiopara is facultatively autotrophic and facultatively anaerobic, and its temperature range for growth is 60 to $80^{\circ} \mathrm{C}(12-14)$. Until recently, this organism was thought to be the only true thermophile that is able to reduce carbon dioxide to organic carbon via the Calvin cycle.

In this paper we describe an aerobic, thermophilic, obligately chemolithoautotrophic, sulfur-oxidizing bacterium belonging to the genus Thermothrix, Thermothrix azorensis sp. nov.

\section{MATERIALS AND METHODS}

Sample collection, isolation procedures, and culture conditions. White filamentous bacterial mat material was collected from a hot spring located at the

\footnotetext{
* Corresponding author.

$\uparrow$ Contribution 8939 of the Woods Hole Oceanographic Institution.

$\ddagger$ Permanent address: Institute of Microbiology, Russian Academy of Sciences, Prospekt 60-letya Oktyabrya, 7/2, Moscow, 117811 Russia.
}

caldera at Furnas on Sao Miguel Island in the Azores. The samples were stored at room temperature for more than 1 month before isolation procedures were started by serially diluting them in medium containing thiosulfate ( $4 \mathrm{mM}$ ) and hydrogen sulfide $(0.5 \mathrm{mM})$ and incubating the preparations at $73^{\circ} \mathrm{C}$. This resulted in isolation of strain $\mathrm{TM}^{\mathrm{T}}(\mathrm{T}=$ type strain). The medium which we used contained (per liter) $0.5 \mathrm{~g}$ of $\left(\mathrm{NH}_{4}\right)_{2} \mathrm{SO}_{4}, 0.1 \mathrm{~g}$ of $\mathrm{MgSO}_{4} \cdot 7 \mathrm{H}_{2} \mathrm{O}, 0.05 \mathrm{~g}$ of $\mathrm{CaCl}_{2} \cdot 2 \mathrm{H}_{2} \mathrm{O}, 0.11 \mathrm{~g}$ of $\mathrm{K}_{2} \mathrm{HPO}_{4}, 0.085 \mathrm{~g}$ of $\mathrm{KH}_{2} \mathrm{PO}_{4}, 0.42 \mathrm{~g}$ of $\mathrm{NaHCO}_{3}, 5 \mathrm{ml}$ of a vitamin mixture (3), and $1 \mathrm{ml}$ of a trace element solution (8). The vitamin and trace element solutions were filter sterilized separately and, after cooling, were added to the autoclaved salt solution. Sodium thiosulfate, potassium tetrathionate, sodium sulfide, elemental sulfur, and sodium bicarbonate were sterilized separately and added, after cooling, to the medium at the final concentrations indicated below. When the following organic compounds were used as potential substrates, they were sterilized by filtration: glucose, arabinose, galactose, fructose, lactose, maltose, lactate, pyruvate, citrate, formate, fumarate, acetate, mannitol, glycine, a mixture of glutamate and serine, and yeast extract. These compounds were added to the medium (concentration range, 0.5 to 5 $\mathrm{g} /$ liter) just prior to inoculation.

Enrichment cultures and, ultimately, pure cultures were grown in either 17-ml screw-top tubes (containing $5 \mathrm{ml}$ of culture medium) or $125-\mathrm{ml}$ flasks (containing $75 \mathrm{ml}$ of culture medium) that were submerged in a heated and covered water bath. For certain growth experiments jacketed chemostat vessels were used. These vessels were connected to a thermocirculator (Haake, Berlin, Germany) to maintain the desired temperature inside the vessel. Sterile air was bubbled continuously through the stirred cultures. Inocula $(10 \%, \mathrm{vol} / \mathrm{vol})$ were grown on medium containing $4 \mathrm{mM}$ thiosulfate. In some experiments the medium was supplemented with sterilized elemental sulfur ("precipitated powder"; final concentration, $1 \mathrm{~g} /$ liter; Fisher Scientific Co., Pittsburgh, Pa.).

A pure culture of $T$. thiopara was kindly provided by Daniel $\mathrm{K}$. Brannan, Abilene, Tex., and was grown on the medium described by Caldwell et al. (16).

Analyses. To determine numbers of cells, cells were fixed in $0.5 \%$ glutaraldehyde in sterile phosphate buffer, stained with $0.01 \%$ acridine orange, and counted by epifluorescence microscopy (22).

Gram staining was performed with a Gram Stain Set kit (Difco). To determine sensitivity to lysozyme, concentrated suspensions of freshly grown cells (12 mg of cell protein per $\mathrm{ml}$ ) in $0.1 \mathrm{M}$ PIPES [piperazine- $N, N^{\prime}$-bis(2-ethanesulfonic acid)] buffer $(\mathrm{pH} \mathrm{7.0)}$ were treated with lysozyme (final concentration, $1 \mathrm{mg} / \mathrm{ml}$ ) for 30 min at $37^{\circ} \mathrm{C}$. The amount of cell lysis was determined microscopically.

Protein content was determined by assaying a preparation with Coomassie blue (11) following hydrolysis of cells in $1 \mathrm{~N} \mathrm{NaOH}$ at $100^{\circ} \mathrm{C}$ for $10 \mathrm{~min}$.

The concentrations of thiosulfate and tetrathionate were determined by the cyanolysis method (25), the concentration of sulfide was determined by the method of Cline (17), the concentration of sulfite was determined by using fuchsin formaldehyde (49), the concentration of sulfate was determined by using $\mathrm{BaCl}_{2}$ and turbidimetry as described by Tabatabai (48), and the concentration of elemental sulfur was determined as described by Odintsova et al. (38).

Microscopy. Cells were examined by phase-contrast microscopy. Photographs 
of living microorganisms were obtained by using wet mounts on agar-coated dry slides that were prepared as described by Pfennig and Wagener (39).

For transmission electron microscopy, cells were fixed with glutaraldehyde and osmium tetroxide, embedded in agar and in Spurr resin, and stained with uranyl acetate and lead citrate by the method of Waterbury and Stanier (52). Thin sections were examined with a Zeiss model $10 \mathrm{CA}$ electron microscope.

Preparation of cell extracts and cell suspensions. The cells used for experiments performed with cell suspensions and enzyme assays were collected from late-log-phase cultures that were centrifuged at $10^{\circ} \mathrm{C}$ and $8,000 \mathrm{rpm}$ for $15 \mathrm{~min}$, washed twice in sterile substrate-free medium and then in $0.1 \mathrm{M}$ PIPES buffer (pH 7.0), and recentrifuged. The resulting pellet was resuspended in the assay buffer. Extracts were prepared by passing cells suspended in the assay buffer three times through a French press at $7,000 \mathrm{lb} / \mathrm{in}^{2}$ and centrifuging the preparation at $12,000 \mathrm{rpm}$ for $20 \mathrm{~min}$ at $4^{\circ} \mathrm{C}$. The resulting supernatant was used immediately in enzyme assays.

For short-term growth experiments, cell suspensions were prepared as follows After two washes the cells were resuspended in $0.25 \mathrm{M}$ Tris- $\mathrm{HCl}$ buffer $(\mathrm{pH} \mathrm{7.5)}$ stirred for $1 \mathrm{~h}$ at $76^{\circ} \mathrm{C}$, recentrifuged, and resuspended in $15 \mathrm{ml}$ of the same buffer. Then the suspension was oxygenated by vigorous stirring with a stirring bar at $76^{\circ} \mathrm{C}$ for $40 \mathrm{~min}$. At time zero, $0.15 \mathrm{~g}$ of sulfur was added.

Lipid analysis. Lipids were extracted, fractionated into neutral and polar lipid classes by using silicic acid, subjected to acid methanolysis to release the hydrophobic core lipids, and analyzed by thin-layer chromatography as described elsewhere $(29,30)$. To analyze and identify hydrophobic lipid components we used a Hewlett-Packard model 5890A gas chromatograph connected to a Hewlett-Packard model 5970 mass selective detector, as well as a HewlettPackard type HP-5 capillary column $(10 \mathrm{~m}$ by $0.1 \mathrm{~mm})$; electron impact spectra were obtained at $70 \mathrm{eV}$.

Measurement of $\mathrm{CO}_{2}$ fixation. Time course experiments in which radiolabeled bicarbonate was used were performed by using $5 \mathrm{ml}$ of preparation in $17-\mathrm{ml}$ tubes with rubber stoppers. The medium which we used contained $0.1 \mu \mathrm{Ci}$ of $\mathrm{NaH}^{14} \mathrm{CO}_{3}$ per $\mathrm{ml}, 0.42 \mathrm{~g}$ of $\mathrm{NaHCO}_{3}$ per liter, and $1 \mathrm{~g}$ of $\mathrm{S}^{0}$ per liter. The inoculum made up $10 \%$ of the volume. All of the components except $\mathrm{S}^{0}$ were mixed thoroughly before they were distributed into tubes. The sterile sulfur suspension was added separately to every tube. The experiments were carried out at $80^{\circ} \mathrm{C}$. At certain times, two tubes were removed from the water bath and analyzed as described by Tuttle et al. (50).

Crude cell extracts were assayed for ribulose-1,5-biphosphate carboxylase/ oxygenase activity by using the procedure of Beudeker et al. (7), as modified by Nelson and Jannasch (37). Fresh spinach extract was used as a control.

Phylogenetic analyses. DNA was isolated by the method of Marmur and Doty (33). The $\mathrm{G}+\mathrm{C}$ content of the DNA was calculated from its melting point in $0.1 \times$ SSC by using salmon sperm DNA $(41.2 \mathrm{~mol} \% \mathrm{G}+\mathrm{C})$ as the reference $(1 \times$ SSC is $0.15 \mathrm{M} \mathrm{NaCl}$ plus $0.015 \mathrm{M}$ sodium citrate).

PCR amplification of the 16S rRNA gene was performed by using the following primers designed by using conserved bacterial sequences (36): forward primer EUB5FOR $\left(5^{\prime}\right.$-TGGAGAGTTTGATCMTGGCTCAG $[\mathrm{M}=\mathrm{A}$ or $\mathrm{C}]$; corresponding to positions 5 to 27 [Escherichia coli rRNA numbering]) and reverse primer DREV (5'-ACGGNTACCTTGTTACGACTT [N = A, G, C, or T]; corresponding to positions 1512 to 1492). The sequences of PCR products were determined directly by using a Sequenase PCR product sequencing kit (Amersham Life Science). The sequences obtained were manually aligned with closely related and representative sequences as determined with the utilities of the Ribosomal Database Project (31). Partial gene sequences were determined for strain TM $^{\mathbf{T}}$ (825 nucleotides; levels of similarity with Alcaligenes eutrophus and T. thiopara, 97 and 92\%, respectively) and for T. thiopara (926 nucleotides; level of similarity with Alcaligenes eutrophus, 98\%). Phylogenetic trees were generated by using the power PC version of the maximum-likelihood algorithm in the PHYLIP package of programs (20). Reference sequences were obtained from the Ribosomal Database Project (31).

\section{RESULTS}

Morphology. Exponentially grown cells of strain $\mathrm{TM}^{\mathrm{T}}$ under optimal conditions were gram-negative, long, thin rods that were 2 to 5 by 0.3 to $0.5 \mu \mathrm{m}$ (Fig. 1). The cells were motile, often occurred in pairs, and were longer (up to $10 \mu \mathrm{m}$ long) at temperatures above the optimum temperature (i.e., at temperatures above $78^{\circ} \mathrm{C}$ ). Around $65^{\circ} \mathrm{C}$, near the lower limit of the temperature range for growth, filaments up to $70 \mu \mathrm{m}$ long were observed, especially at the beginning of the log phase. When oxidation of thiosulfate was incomplete for any reason and the $\mathrm{pH}$ was not below 7.0, cells often contained inclusions of elemental sulfur.

General growth characteristics. Strain $\mathrm{TM}^{\mathrm{T}}$ was isolated from serial dilutions in medium containing thiosulfate and hydrogen sulfide. Strain $\mathrm{TM}^{\mathrm{T}}$ grew aerobically and chemolithoautotrophically with hydrogen sulfide, thiosulfate, tetra-
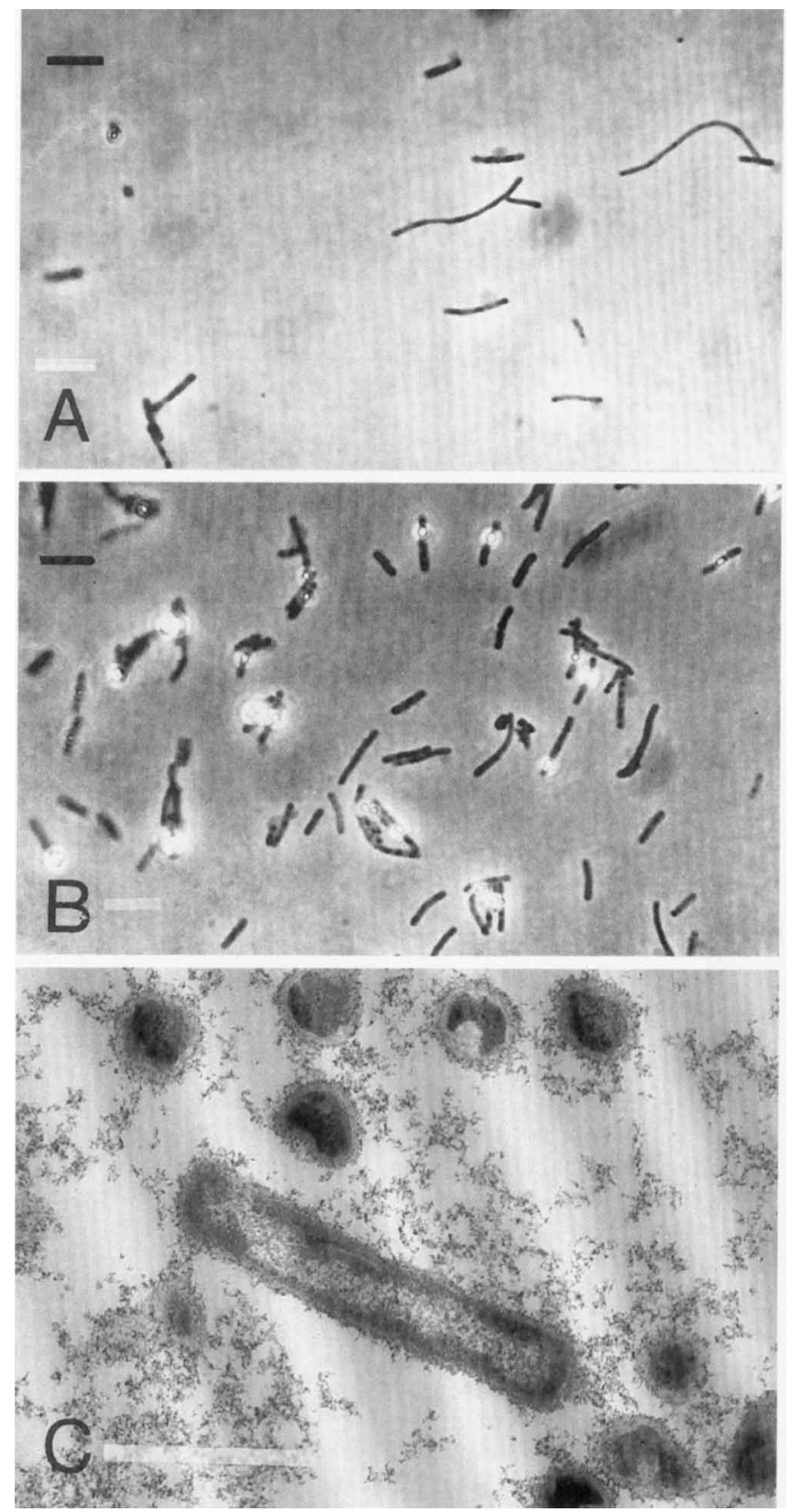

FIG. 1. Cell morphology of strain $\mathrm{TM}^{\mathrm{T}}$ grown in thiosulfate medium at $76^{\circ} \mathrm{C}$. (A) Cells of various lengths from the late lag phase. Bar $=5 \mu \mathrm{m}$. (B) Cells with sulfur inclusions from the exponential growth phase. Bar $=5 \mu \mathrm{m}$. (C) Transmission electron micrograph of a section containing exponentially grown cells. Bar $=1 \mu \mathrm{m}$.

thionate, or sulfur as the electron donor. It did not grow heterotrophically with any of the following organic compounds: glucose, arabinose, galactose, fructose, lactose, maltose, lactate, pyruvate, citrate, formate, fumarate, acetate, mannitol, glycine, a mixture of glutamate and serine, and yeast extract (concentration range tested, 0.5 to $5 \mathrm{~g}$ /liter). Growth on thiosulfate $(0.5$ to $1 \mathrm{~g} /$ liter $)$ was not inhibited by glucose, acetate, lactate, mannitol, fumarate, arabinose, galactose, lactose, maltose, citrate, pyruvate, or yeast extract, and these organic compounds did not increase the cell yield during growth on thiosulfate (data not shown). Thus, strain $\mathrm{TM}^{\mathrm{T}}$ did not grow mixotrophically. 


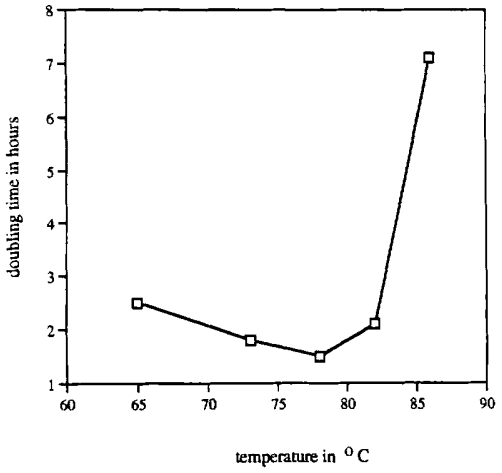

FIG. 2. Effect of temperature on the doubling time of strain $\mathrm{TM}^{\mathrm{T}}$ during growth on elemental sulfur.

When thiosulfate was replaced with methionine $(0.5 \mathrm{~g} /$ liter $)$ as the sulfur source, strain $\mathrm{TM}^{\mathrm{T}}$ did not grow in the presence or absence of organic compounds.

No growth occurred in the presence of hydrogen with or without sulfur or thiosulfate (the gas mixture contained $5 \%$ air). Growth did not occur anaerobically when thiosulfate, sulfur, or an organic compound was used as the electron donor and nitrate was used as the electron acceptor or when hydrogen was used as the electron donor and sulfur or thiosulfate was used as the electron acceptor. Strain $\mathbf{T M}^{\mathrm{T}}$ appeared to be an obligately aerobic autotroph.

Strain $\mathrm{TM}^{\mathrm{T}}$ grew well at 63 to $86^{\circ} \mathrm{C}$, and the optimum temperature was 76 to $78^{\circ} \mathrm{C}$. When this organism was grown on elemental sulfur at the optimum temperature, the doubling time of the culture was $1.5 \mathrm{~h}$ (Fig. 2). At $86^{\circ} \mathrm{C}$ the number of cells doubled only once, probably because of increased maintenance metabolism, but it was possible to subculture the organism at this temperature. When cells were grown on elemental sulfur, the typical lag phase was strongly affected by the temperature. The length of the lag phase decreased with increasing temperature.

Generally, strain $\mathrm{TM}^{\mathrm{T}}$ grew at $\mathrm{pH} 6.0$ to 8.5 , and the optimum $\mathrm{pH}$ was close to 7.1 (Fig. 3). At $\mathrm{pH} 8.5$, filaments up to 30 $\mu \mathrm{m}$ long formed.

Strain $\mathrm{TM}^{\mathrm{T}}$ can be stored in liquid nitrogen with dimethyl sulfoxide, a method devised by Connaris et al. (18).

Autotrophic growth of strain $\mathbf{T M}^{\mathbf{T}}$ on thiosulfate and sulfur. Growth of strain $\mathrm{TM}^{\mathrm{T}}$ on thiosulfate resulted in production of sulfate, and extracellular sulfur was an intermediate metabo-

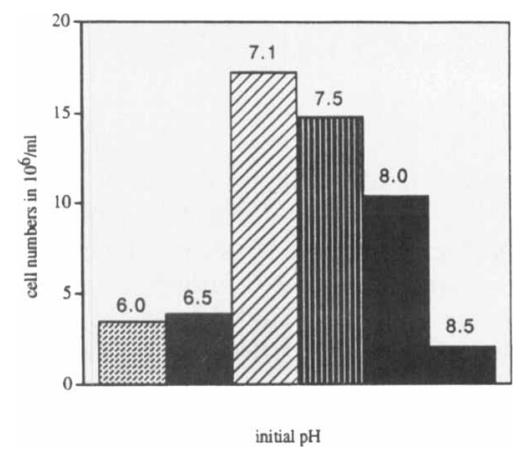

FIG. 3. Effect of initial $\mathrm{pH}$ on the yield (cell count) of strain $\mathbf{T M}^{\mathbf{T}}$ grown on elemental sulfur at $70^{\circ} \mathrm{C}$ over a 23 -h period in the growth medium described in Materials and Methods in the absence of buffers. The initial cell concentration was $0.8 \times 10^{6}$ cells per $\mathrm{ml}$.

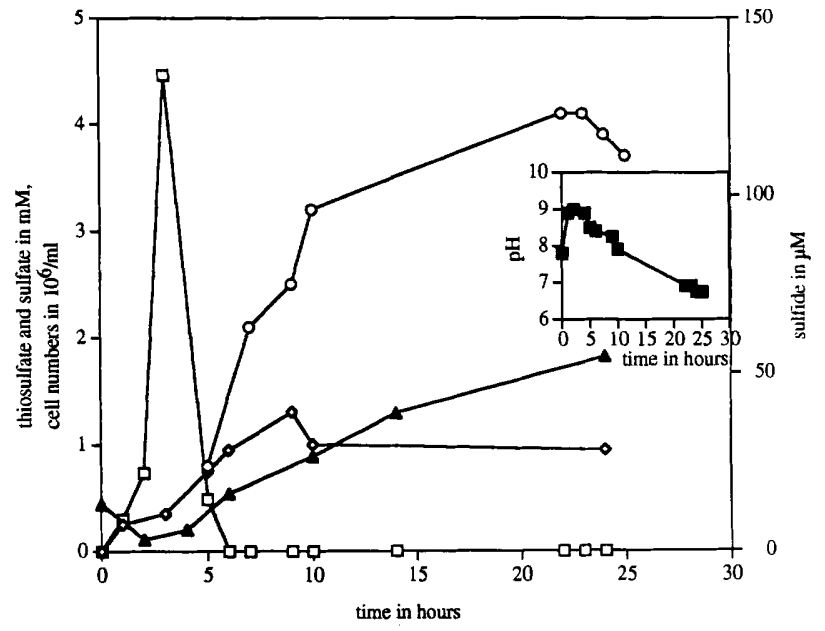

FIG. 4. Reduction of sulfur to sulfide ( $\square$ ) and subsequent oxidation to thiosulfate $(\bigcirc)$ and sulfate $(\diamond)$, as well as growth (determined as cell counts [ $\Delta]$ ) in cultures of strain $\mathrm{TM}^{\mathrm{T}}$ at $81^{\circ} \mathrm{C}$.

lite. No polythionates were detected. When the initial thiosulfate concentration was $18.25 \mathrm{mM}$, growth stopped when the concentration of the substrate was $8 \mathrm{mM}$, apparently because of a decrease in $\mathrm{pH}$. The initial $\mathrm{pH}$ was 7.5 , and the $\mathrm{pH}$ increased significantly during the first $1 \mathrm{~h}$, reached a value of 9.2, and then decreased gradually to a value of 6.0 at the end of the growth period. When the initial concentration of thiosulfate in the culture was $7.5 \mathrm{mM}$, almost all of the substrate was used within $17.5 \mathrm{~h}$; in this experiment the residue consisted of $0.1 \mathrm{mM}$ thiosulfate, and the final $\mathrm{pH}$ was 5.6.

Independent of the initial $\mathrm{pH}$ of the medium, the $\mathrm{pH}$ increased to 8.7 to 9.0 in several experiments during the first $1 \mathrm{~h}$ of growth on thiosulfate or sulfur (Fig. 4). The $\mathrm{pH}$ then decreased gradually, leveling out at around 6.5. Growth on elemental sulfur appeared to be inhibited when $20 \mathrm{mM}$ HEPES ( $N$-2-hydroxyethylpiperazine- $N^{\prime}$-2-ethanesulfonic acid) buffer was added to the medium. This indicated that the initial increase in $\mathrm{pH}$ may have favored activation of elemental sulfur as a substrate. Buffering did not affect growth on thiosulfate.

Growth on elemental sulfur under strictly aerobic conditions with constant mixing was preceded by a lag phase accompanied by production of sulfide and a rapid increase in $\mathrm{pH}$ (Fig. 4). Thiosulfate was the major end product, and sulfate was the minor end product. Under these conditions the thiosulfate

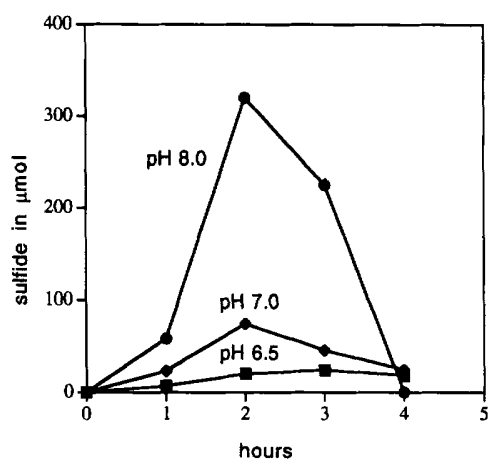

FIG. 5. Abiological production of sulfide from elemental sulfur at three different initial $\mathrm{pH}$ values under aerobic conditions at $81^{\circ} \mathrm{C}$ in growth medium without cells. 


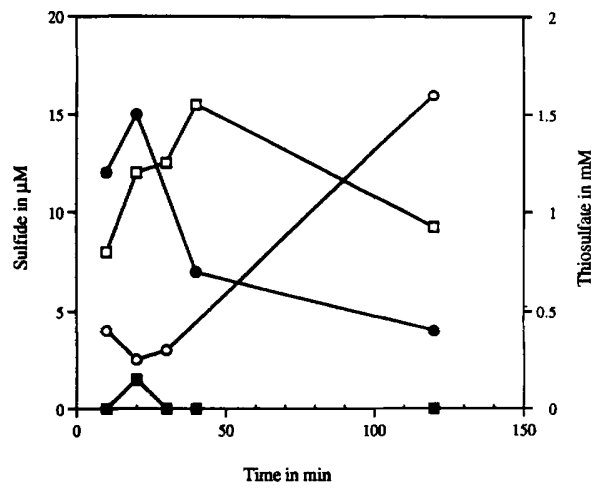

FIG. 6. Production of sulfide $(\square)$ and thiosulfate $(O)$ from elemental sulfur by suspensions of starved and washed cells (prepared as described in Materials and Methods) of strain $\mathrm{TM}^{\mathrm{T}}$ at $76^{\circ} \mathrm{C}$. The amount of biomass was determined by determining the amount of protein $(42.5 \mathrm{mg} /$ liter $)$. We also examined the production of sulfide $(\boldsymbol{\square})$ and thiosulfate $(\boldsymbol{O})$ in a control that contained buffer $(0.25$ $\mathrm{M}$ Tris- $\mathrm{HCl})$ and sulfur $(0.1 \mathrm{~g} / \mathrm{ml})$ but no cells.

concentration increased gradually from the time of sulfide disappearance and started to decrease only when growth ceased toward the end of the experiment. The decrease in $\mathrm{pH}$ to about 6.0 coincided with the end of thiosulfate oxidation.

Under the conditions used in the growth experiments (culture volume, $300 \mathrm{ml}$; vigorous stirring for aeration; sulfur concentration, $1 \mathrm{~g} /$ liter), abiotic controls also produced sulfide (Fig. 5). This chemical reduction depended on the $\mathrm{pH}$; the higher the initial $\mathrm{pH}$, the higher the sulfide concentration. After a few hours, the sulfide concentration decreased to a level below the level of detection. Regardless of the initial value (obtained by adding $2 \mathrm{mM} \mathrm{NaHCO}_{3}$ or $1 \mathrm{M} \mathrm{HCl}$ to the base medium), the $\mathrm{pH}$ increased during the first $1 \mathrm{~h}$ to 8.7 and then decreased gradually.

The reason for the brief appearance of sulfide during the lag phase of the culture and the apparent absence of detectable sulfide thereafter might be that all of the sulfur was solubilized during the initial $\mathrm{pH}$ peak and then oxidized during the time when the $\mathrm{pH}$ was decreasing.

In order to distinguish between chemical and biological sulfide production from elemental sulfur in growing cultures, short-term experiments were conducted with suspensions of starved and washed (nongrowing) cells in Tris- $\mathrm{HCl}$ buffer (Fig. 6) at $\mathrm{pH}$ 7.5. Uninoculated controls were examined in parallel. After an initial increase in the sulfide concentration for $40 \mathrm{~min}$, the sulfide concentration started to decrease while the thiosulfate concentration increased. In the uninoculated controls only an insignificant amount of sulfide was detected initially, while the level of thiosulfate increased during the first $20 \mathrm{~min}$ and decreased subsequently to $0.4 \mathrm{mM}$. These results support the notion that most of the initial sulfide production was indeed biological sulfide production.

$\mathrm{CO}_{2}$ fixation. When strain $\mathrm{TM}^{\mathrm{T}}$ was grown on sulfur at $80^{\circ} \mathrm{C}$, the total uptake of radiolabeled sodium bicarbonate during a 9-h experiment was $17.45 \mu \mathrm{g}$ of $\mathrm{HCO}_{3}^{-}$fixed per $10^{6}$ cells. The average rate was $1.9 \mu \mathrm{g}$ of $\mathrm{HCO}_{3}{ }^{-}$, fixed per $10^{6}$ cells per $\mathrm{h}$.

This autotrophic activity was similar to the activities reported previously for other autotrophic bacteria. $T$. thiopara fixed carbon through the Calvin cycle (14), like most aerobic autotrophic eubacteria. However, activity of ribulose-1,5-biphosphate carboxylase, the key enzyme of the Calvin cycle, was not detected in our experiments. Likewise, ribulose-1,5-biphosphate carboxylase/oxygenase form I and II antibodies did not cross-react with a cell extract. The possibility that fixation of

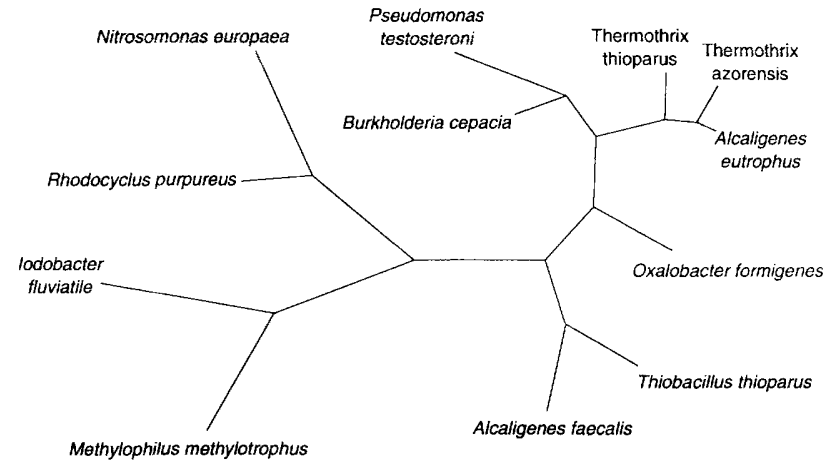

0.1

FIG. 7. Phylogenetic positions of $T$. azorensis and $T$. thioparus among representative $\beta$ subdivision protobacteria inferred from the results of $16 \mathrm{~S}$ rRNA sequence analyses. Scale bar $=0.1$ change per nucleotide position.

carbon occurs via the reductive tricarboxylic acid cycle is being investigated at this time.

Chemotaxonomic characteristics. Lipid analyses revealed that the hydrophobic core lipids of strain $\mathrm{TM}^{\mathrm{T}}$ were composed solely of typical eubacterial $n-\mathrm{C}_{14}$ to $n-\mathrm{C}_{22}$ fatty acids, with $n-\mathrm{C}_{16}$ and $n-\mathrm{C}_{18}$ accounting for about $95 \%$ of the total. Archaebacterial isoprenoid ether lipids, long-chain diols, nonisoprenoid diether, and the long-chain dicarboxylic fatty acids that are characteristic of several different thermophilic eubacterial groups were not present in strain $\mathrm{TM}^{\mathrm{T}}$.

The DNA base composition of strain $\mathrm{TM}^{\mathrm{T}}$ was $39.7 \mathrm{~mol} \%$ $\mathrm{G}+\mathrm{C}$, which is the value obtained for T. thiopara. This value is similar to the DNA base compositions of bacteria belonging to the strictly chemolithoautotrophic hydrogen-oxidizing genera Hydrogenobacter and Calderobacterium (44).

The 16S rRNA sequence of strain TM ${ }^{\mathrm{T}}$ placed this organism in the $\beta$ subdivision of the Proteobacteria (Fig. 7), indicating that it is closely related to the genera Alcaligenes and Pseudomonas.

\section{DISCUSSION}

We found that strain $\mathrm{TM}^{\mathrm{T}}$ is a thermophilic, obligately autotrophic, aerobic bacterium that grows on reduced sulfur compounds. This organism is gram negative and sensitive to lysozyme and has a lipid composition that is common among eubacteria. Its morphological features, including the ability to form filaments, are similar to those of $T$. thiopara $(12,14)$. However, strain $\mathrm{TM}^{\mathrm{T}}$ differs from the only previously described Thermothrix species ( $T$. thiopara) by being strictly chemolithoautotrophic; it does not grow heterotrophically under aerobic or anaerobic conditions. In addition, strain $\mathrm{TM}^{\mathrm{T}}$ has higher optimum and maximum growth temperatures than T. thiopara, and the $\mathrm{G}+\mathrm{C}$ contents of the DNAs of the two organisms are the same $(39.7 \mathrm{~mol} \%)$. Both organisms appear to belong to the same genus of thermophilic sulfur-oxidizing bacteria but different species.

Geothermal springs are often colonized by bacteria that produce streamers, which are visible as a network of filaments and single cells. Previous attempts to isolate these filaments usually resulted in cultures of rod-shaped bacteria that produced filaments only under certain conditions. The only truly filamentous thermophilic bacterium that has been described so far belongs to genus Thermus (23). T. thiopara produces filaments only when oxygen is the growth-limiting factor (14), and 
Acetothermus paucivorans, an anaerobic thermophilic bacterium, forms filaments only in the absence of vitamin $B_{12}$ (19). Acetothermus cellulolyticus formed filaments when it was first isolated but lost this morphological characteristic after repeated transfers (35). Members of the genus Hydrogenobacter have been reported to form filaments sometimes when they are incubated at temperatures above the optimal growth temperature (2).

Strain $\mathrm{TM}^{\mathrm{T}}$ produced filaments under unfavorable conditions (e.g., when it was grown at a temperature near the maximum temperature and at extreme $\mathrm{pH}$ values). As in the case of Hydrogenobacter strains, filament formation in thermophilic bacteria may be a reaction to stress. Since the conditions in natural environments are variable and most of the time far from favorable, filamentous forms or streamers are observed most often in situ. In a recent phylogenetic study (40) of a well-known pink community of filamentous organisms in the 84 to $88^{\circ} \mathrm{C}$ outflow of Octopus Spring in Yellowstone National Park, it was shown that the filaments are most closely related to the hydrogen-oxidizing bacterium Aquifex pyrophilus and its close relative Hydrogenobacter thermophilus. When these organisms were grown in culture, however, both of them occurred as unicellular bacteria.

An unusual observation was the initial reduction of elemental sulfur to sulfide in aerobic cultures of strain $\mathrm{TM}^{\mathrm{T}}$. This reduction occurred during the lag phase (i.e., when there was no increase in cell biomass). Reduction of elemental sulfur is common in anaerobic cultures of hyperthermophilic archaea and bacteria in which hydrogen, the electron donor, occurs as a fermentation product. Desulfurolobus ambivalens and one of the Sulfolobus species are able to grow either anaerobically by reducing sulfur or aerobically by oxidizing sulfur depending on the oxygen supply $(42,55,56)$. The sulfur oxygenase reductase of $D$. ambivalens simultaneously produces sulfite, thiosulfate, and hydrogen sulfide from sulfur in the presence of oxygen (26, 27). This enzyme was not detected in anaerobically grown cells. It is possible that a similar enzyme is responsible for sulfur utilization in cultures of strain $\mathbf{T M}^{\mathbf{T}}$.

Hydrogen sulfide was not detected in cultures of strain $\mathrm{TM}^{\mathrm{T}}$ after the lag phase (Fig. 4). It is possible that in this organism sulfide serves as a sulfur nucleophile, as defined by Blumentals et al. (9), and that it solubilizes elemental sulfur, as has been shown for the anaerobic hyperthermophilic archaeon Pyrococcus furiosus (9).

In order to utilize sulfur, both mesophilic and thermophilic bacteria must either have direct contact with the solid sulfur substrate or mediate conversion of the sulfur ring to a soluble compound. The most likely elemental sulfur solubilization reaction is formation of polysulfides $(9,41)$. However, in aqueous solutions polysulfides are not stable at $\mathrm{pH}$ values below 8.7 , and it has been shown that no sulfur solubilization occurs at pH 7.0 (9). Thus, in cultures of strain $\mathrm{TM}^{\mathrm{T}}$ initial sulfide production from elemental sulfur should lead to the increase in $\mathrm{pH}$ necessary for sulfur solubilization.

Sulfide ions $\left(\mathrm{S}^{2-}\right.$ and $\left.\mathrm{HS}^{-}\right)$are probably the most important sulfur nucleophiles present in bacterial systems. The initial ring-opening reaction, $\mathrm{S}_{8}+\mathrm{HS}^{-} \rightarrow \mathrm{S}_{8} \mathrm{~S}^{2-}+\mathrm{H}^{+}$, is followed by rapid chain degradation and establishment of an equilibrium among polysulfide ions of different sizes $\left(S_{m}, S_{n}\right)$, as well as sulfide and hydroxyl ions, according to the following reaction (9): $\mathrm{S}_{\mathrm{m}+\mathrm{n}} \mathrm{S}^{2-}+\mathrm{HS}^{-}+\mathrm{OH}^{-} \rightarrow \mathrm{S}_{\mathrm{m}} \mathrm{S}^{2-}+\mathrm{S}_{\mathrm{n}} \mathrm{S}^{2-}+\mathrm{H}_{2} \mathrm{O}$.

At high temperatures and near neutral $\mathrm{pH}$, polysulfides apparently are chemically produced as intermediates from sulfur reduction and are subsequently utilized biologir ally (41). Polysulfides have also been identified as soluble intermediates during sulfur respiration by Wolinella succinogenes (28). In this connection it should be remembered that the energy threshold for sulfur reduction appears to be lower at temperatures above $80^{\circ} \mathrm{C}$ and that under anoxic conditions sulfide is produced abiologically (6). In aerobic sulfur-oxidizing bacteria, however, initial sulfide production has not been reported previously, and this phenomenon certainly should be studied further. The sulfide produced in cultures of strain $\mathrm{TM}^{\mathrm{T}}$ during the lag phase could serve the following two purposes: it could increase the $\mathrm{pH}$ for polysulfide stability, and it could accelerate sulfur solubilization, making sulfur available for oxidation.

Until recently, it was thought that all gram-negative aerobic autotrophic bacteria use the enzymatic Calvin cycle for $\mathrm{CO}_{2}$ fixation. However, the recent isolation and studies of thermophilic hydrogen-oxidizing bacteria belonging to the genera $H y$ drogenobacter and Aquifex revealed that the reductive tricarboxylic acid cycle also occurs in aerobic autotrophic eubacteria $(5,24,43,44)$. So far, this cycle appears to be restricted to these two genera, which form the deepest branch on the bacterial phylogenetic tree $(40,45)$. It is interesting, therefore, that strain $\mathrm{TM}^{\mathrm{T}}$, which is not related to the hydrogen-oxidizing thermophiles, also did not exhibit ribulose-1,5-biphosphate carboxylase/oxygenase activity. The closest relative of strain $\mathrm{TM}^{\mathrm{T}}, T$. thiopara, was originally reported to have ribulose-1,5biphosphate carboxylase/oxygenase activity (14). Later, however, this could not be confirmed, and a $\mathrm{C}_{4}$ pathway was suggested for $\mathrm{CO}_{2}$ fixation (34). Besides a phylogenetic basis for the absence of the Calvin cycle in autotrophic thermophilic bacteria, a number of other factors, such as growth temperature, might be responsible.

The results of our phylogenetic analysis of partial rRNA sequences suggested that strain $\mathrm{TM}^{\mathrm{T}}$ and $T$. thiopara are closely related species that belong to the $\beta$ subdivision of the Proteobacteria (formerly the purple bacteria and their relatives) (46). The genus Thermothrix appears to contain the only thermophilic bacteria in the $\beta$ subdivision. Figure 7 shows the relationship of members of this genus to representatives of the various other subdivisions of the Proteobacteria. Although the DNA base composition of strain $\mathrm{TM}^{\mathrm{T}}$ is similar to the DNA base compositions of the thermophilic hydrogen-oxidizing bacteria, strain $\mathrm{TM}^{\mathrm{T}}$ can be separated from these bacteria on the basis of physiological properties and phylogenetic position.

Description of Thermothrix azorensis sp. nov. Thermothrix azorensis Odintsova, Jannasch, Mamone, and Langworthy (a.zo'ren.sis. L. fem. adj. azorensis, from the Azores).

Cells are long thin rods that are 2 to 5 by 0.3 to $0.5 \mu \mathrm{m}$ and often occur in pairs. Filaments up to $70 \mu \mathrm{m}$ long are produced under unfavorable growth conditions. Cells are gram negative and nonsporulating and may contain sulfur inclusions. The organism is strictly aerobic and obligately chemolithoautotrophic and uses reduced sulfur compounds (hydrogen sulfide, elemental sulfur, tetrathionate, and thiosulfate) as electron donors and carbon dioxide as a carbon source. During the lag phase oxidation of elemental sulfur is preceded by production of sulfide.

The temperature range for optimum growth is 76 to $78^{\circ} \mathrm{C}$, and the temperature extremes are 60 and $87^{\circ} \mathrm{C}$. Growth occurs at $\mathrm{pH} 6.0$ to 8.5 , and the optimum $\mathrm{pH}$ is 7.0 to 7.5 .

The lipid fatty acids include $n-\mathrm{C}_{14}$ to $n-\mathrm{C}_{22}$ fatty acids, with $n-\mathrm{C}_{16}$ and $n-\mathrm{C}_{18}$ fatty acids accounting for $95 \%$ of the total fatty acids.

The $\mathrm{G}+\mathrm{C}$ content of the DNA is $39.7 \mathrm{~mol} \%$. As determined by a $16 \mathrm{~S}$ rRNA sequence analysis, our new isolate is affiliated with the $\beta$ subdivision of the Proteobacteria.

T. azorensis was isolated from a hot spring located at the caldera at Furnas, Sao Miguel, the Azores, Portugal. 
The type strain is strain TM, which has been deposited in the American Type Culture Collection as strain ATCC 51754.

\section{ACKNOWLEDGMENTS}

We are grateful to Carl O. Wirsen and Stephen J. Molyneaux for enormous help and fruitful discussions, to Diana Franks for assistance with the transmission electron microscopy, and to Jonathan Robinson and Coleen Cavanaugh (Harvard University, Cambridge, Mass.) for performing antibody tests to determine the presence of ribulose-1,5biphosphate carboxylase/oxygenase. We especially thank Karl O. Stetter (Regensburg, Germany) for advice and encouragement during sampling.

We acknowledge financial support received from the U.S. Biochemical Corporation and from National Science Foundation grant OCE9200458.

\section{REFERENCES}

1. Alfredsson, G. A., A. Ingason, and J. K. Kristjansson. 1986. Growth of thermophilic, obligately autotrophic hydrogen-oxidizing bacteria on thiosulfate. Lett. Appl. Microbiol. 2:21-24.

2. Aragno, M. 1992. Aerobic, chemolithoautotrophic, thermophilic bacteria, p 77-103. In J. K. Kristjansson (ed.), Thermophilic bacteria. CRC Press, Inc., Boca Raton, Fla.

3. Bazylinski, D. A., C. O. Wirsen, and H. W. Jannasch. 1989. Microbial utilization of naturally occurring hydrocarbons at the Guaymas Basin hydrothermal vent site. Appl. Environ. Microbiol. 55:2832-2836.

4. Beffa, T., M. Berzcy, and M. Aragno. 1993. Elemental sulfur production during mixotrophic growth on hydrogen and thiosulfate of thermophilic hydrogen-oxidizing bacteria. Curr. Microbiol. 27:349-353.

5. Beh, M., G. Strauss, R. Huber, K. O. Stetter, and G. Fuchs. 1993. Enzymes of the reductive citric acid cycle in the autotrophic eubacterium Aquifex pyrophilus and in the archaebacterium Thermoproteus neutrophilus. Arch. Microbiol. 160:306-311.

6. Belkin, S., C. O. Wirsen, and H. W. Jannasch. 1985. Biological and abiological sulfur reduction at high temperatures. Appl. Environ. Microbiol. 49:1057-1061.

7. Beudeker, R. F., G. C. Cannon, J. G. Kuenen, and J. M. Shively. 1980. Relations between d-ribulose-1,5-biphosphate carboxylase, carboxysomes and $\mathrm{CO}_{2}$ fixing capacity in the obligate chemolithotroph Thiobacillus neapolitanus grown under different limitations in the chemostat. Arch. Microbiol. 124:185-189.

8. Biebl, H., and N. Pfennig. 1978. Growth yields of green sulfur bacteria in mixed cultures with sulfur and sulfate reducing bacteria. Arch. Microbiol. 117:9-16.

9. Blumentals, I. I., M. Iton, G. J. Olson, and R. M. Kelly. 1990. Role of polysulfides in reduction of elemental sulfur by the hyperthermophilic archaebacterium Pyrococcus furiosus. Appl. Environ. Microbiol. 56:1255-1262.

10. Bonjour, F., and M. Aragno. 1986. Growth of thermophilic obligatorily chemolithoautotrophic hydrogen-oxidizing bacteria related to Hydrogenobacter with thiosulfate and elemental sulfur as electron and energy source. FEMS Microbiol. Lett. 35:11-15.

11. Bradford, M. M. 1976. A rapid and sensitive method for the quantitation of microgram quantities of protein utilizing the principle of protein-dye binding. Anal. Chem. 72:248-254.

12. Brannan, D. K., and D. E. Caldwell. 1980. Thermothrix thiopara: growth and metabolism of a newly isolated thermophile capable of oxidizing sulfur and sulfur compounds. Appl. Environ. Microbiol. 40:211-216.

13. Brannan, D. K., and D. E. Caldwell. 1983. Growth kinetics and yield coefficients of the extreme thermophile Thermothrix thiopara in continuous culture. Appl. Environ. Microbiol. 45:169-173.

14. Brannan, D. K., and D. E. Caldwell. 1986. Ecology and metabolism of Thermothrix thiopara. Adv. Appl. Microbiol. 31:233-270.

15. Brierly, J. A., P. R. Norris, D. P. Kelly, and N. W. LeRoux. 1978. Characteristics of a moderately thermophilic and acidophilic iron-oxidizing Thiobacillus. Eur. J. Appl. Microbiol. Biotechnol. 5:291-299.

16. Caldwell, D. E., S. J. Caldwell, and J. P. Laycock. 1976. Thermothrix thioparus gen. et sp. nov., a facultatively anaerobic facultative chemolithoautotroph living at neutral $\mathrm{pH}$ and high temperature. Can. J. Microbiol. 22:1509-1517.

17. Cline, J. D. 1969 . Spectrophotometric determination of hydrogen sulfide in natural waters. Limnol. Oceanogr. 14:454-458.

18. Connaris, H., D. Cowan, M. Ruffet, and R. J. Sharp. 1991. Preservation of the hyperthermophile Pyrococcus furiosus. Lett. Appl. Microbiol. 13:25-27.

19. Dietrich, G., N. Weiss, and J. Winter. 1988. Acetothermus paucivorans, gen. nov., sp. nov., a strictly anaerobic, thermophilic bacterium from sewage sludge, fermenting hexoses to acetate, $\mathrm{CO}_{2}$ and $\mathrm{H}_{2}$. Syst. Appl. Microbiol. 10:174-179.

20. Felsenstein, J. 1989. PHYLIP-phylogeny inference package (version 3.2). Cladistics 5:164-166.
21. Golovacheva, R. S., and G. I. Karavaiko. 1978. A new genus of thermophilic spore-forming bacteria, Sulfobacillus. Mikrobiologiya 47:658-663.

22. Hobbie, J. E., R. J. Daley, and S. Jasper. 1977. Use of Nuclepore filters for counting bacteria by fluorescence microscopy. Appl. Environ. Microbiol. 33: $1225-1228$.

23. Hudson, J. A., H. W. Morgan, and R. M. Daniel. 1987. Thermus filiformis sp. nov., a filamentous caldoactive bacterium. Int. J. Syst. Bacteriol. 37:431-436.

24. Ishii, M., Y. Igarashi, and T. Kodama. 1989. Purification and characterization of ATP:citrate lyase from Hydrogenobacter thermophilus TK-6. J. Bacteriol. 171:1788-1792.

25. Kelly, D. P., L. A. Chambers, and P. A. Trudinger. 1969. Cyanolysis and spectrophotometric estimation of trithionate in mixture with thiosulfate and tetrathionate. Anal. Chem. 41:898-901.

26. Kletzin, A. 1989. Coupled enzymatic production of sulfite, thiosulfate, and hydrogen sulfide from sulfur: purification and properties of a sulfur oxygenase reductase from the facultatively anaerobic archaebacterium Desulfurolobus ambivalens. J. Bacteriol. 171:1638-1643.

27. Kletzin, A. 1994. Sulfur oxidation and reduction in Archaea: sulfur oxygenase-reductase and hydrogenases from the extremely thermophilic and facultatively anaerobic archaeon Desulfurolobus ambivalens. Syst. Appl. Microbiol. 16:534-543.

28. Klimmek, O., A. Kroger, R. Steudel, and G. Holdt. 1991. Growth of Wolinella succinogenes with polysulfide as terminal acceptor of phosphorylative electron transport. Arch. Microbiol. 155:177-182.

29. Langworthy, T. A. 1982. Lipids of Thermoplasma. Methods Enzymol. 88:396406.

30. Langworthy, T. A., G. Holzer, J. G. Zeikus, and T. G. Tornebene. 1983. Isoand anteiso-branched glycerol diethers of the thermophilic anaerobe Thermodesulfotobacterium commune. Syst. Appl. Microbiol. 4:1-17.

31. Larson, N., G. J. Olsen, B. L. Maidak, M. J. McCaughey, R. Overbeek, T. J. Macke, T. L. Marsh, and C. R. Woese. 1993. The Ribosomal Database Project. Nucleic Acids Res. 21(Suppl.):3021-3023.

32. LeRoux, N. W., D. S. Wakerley, and S. D. Hunt. 1977. Thermophilic thiobacillus-type bacteria from Icelandic thermal areas. J. Gen. Microbiol. 100: 197-201.

33. Marmur, J., and P. Doty. 1962. Determination of the base composition of deoxyribonucleic acid from its thermal denaturation temperature. J. Mol. Biol. 5:109-118.

34. Meritt, K., A. Poynor, and D. Brannan. 1991. Absence of ribulose-1,5biphosphate carboxylase in Thermothrix thiopara suggests a $\mathrm{C}_{4}$ carbon dioxide fixation pathway, abstr. I-51, p. 199. In Abstracts of the 91st General Meeting of the American Society for Microbiology 1991. American Society for Microbiology, Washington, D.C.

35. Mohagheghi, A., K. Grohmann, M. Himmel, L. Leighton, and D. M. Updergraff. 1986. Isolation and characterization of Acidothermus cellulolyticus gen. nov., sp. nov., a new genus of thermophilic, acidophilic, cellulolytic bacteria. Int. J. Syst. Bacteriol. 36:435-443.

36. Neefs, J.-M., V. de Peer, L. Hendriks, and R. De Wachter. 1990. Compilation of small ribosomal subunit RNA sequences. Nucleic Acids Res. 18(Suppl.): $2237-2317$.

37. Nelson, D. C., and H. W. Jannasch. 1983. Chemoautotrophic growth of a marine Beggiatoa in sulfide-gradient cultures. Arch. Microbiol. 136:262-269.

38. Odintsova, E. V., A. P. Wood, and D. P. Kelly. 1993. Chemolithoautotrophic growth of Thiothrix ramosa. Arch. Microbiol. 160:152-157.

39. Pfennig, N., and S. Wagener. 1986. An improved method of preparing wet mounts for photomicrographs of microorganisms. J. Microbiol. Methods 4:303-306.

40. Reysenbach, A.-L., G. S. Wickham, and N. R. Pace. 1994. Phylogenetic analysis of the hyperthermophilic pink filament community in Octopus Spring, Yellowstone National Park. Appl. Environ. Microbiol. 60:2113-2119.

41. Schauder, R., and E. Muller. 1993. Polysulfide as a possible substrate for sulfur-reducing bacteria. Arch. Microbiol. 160:377-382.

42. Segerer, A., K. O. Stetter, and F. Klink. 1985. Two contrary modes of chemolithotrophy in the same archaebacterium. Nature (London) 313:787-789.

43. Shiba, H., T. Kawasumi, Y. Igarashi, T. Kodoma, and Y. Minoda. 1985. The $\mathrm{CO}_{2}$ assimilation via the reductive tricarboxylic acid cycle in an obligately autotrophic aerobic hydrogen-oxidizing bacterium, Hydrogenobacter thermophilus. Arch. Microbiol. 142:198-203.

44. Shima, S., and K.-I. Suzuki. 1993. Hydrogenobacter acidophilus sp. nov., a thermoacidophilic, aerobic, hydrogen-oxidizing bacterium requiring elemental sulfur for growth. Int. J. Syst. Bacteriol. 43:703-708.

45. Shima, S., M. Yanagi, and H. Saiki. 1994. The phylogenetic position of Hydrogenobacter acidophilus based on 16S rRNA sequence analysis. FEMS Microbiol. Lett. 119:119-122.

46. Stackebrandt, E., R. G. E. Murray, and H. G. Trüper. 1988. Proteobacteria classis nov., a name for the phylogenetic taxon that includes the "purple bacteria and their relatives." Int. J. Syst. Bacteriol. 38:321-325.

47. Stetter, K. O., G. Fiala, G. Huber, R. Huber, and A. Segerer. 1990. Hyperthermophilic microorganisms. FEMS Microbiol. Rev. 75:117-124.

48. Tabatabai, M. A. 1974. A rapid method for determination of sulfate in water samples. Environ. Lett. 7:237-243.

49. Trüper, H. G., and H. G. Schlegel. 1964. Sulfur metabolism in Thiorodaceae. 
I. Quantitative measurements on growing cells of Chromatium okenii. Antonie van Leeuwenhoek J. Microbiol. Serol. 30:225-238.

50. Tuttle, J. H., P. E. Holmes, and H. W. Jannasch. 1977. Thiosulfate stimulation of microbial dark assimilation of carbon dioxide in shallow marine waters. Microb. Ecol. 4:9-25.

51. Vartanyan, N. S., T. A. Pivovarova, I. A. Tsaplina, A. M. Lysenko, and G. I. Karavaiko. 1988. New thermoacidophilic bacterium of the genus Sulfobacillus. Mikrobiologiya 57:268-273.

52. Waterbury, J. B., and R. Y. Stanier. 1978. Patterns of growth and development in pleurocapsalean cyanobacteria. Microbiol. Rev. 42:2-44.

53. Williams, R. A. D., and D. S. Hoare. 1972. Physiology of a new facultatively autotrophic thermophilic thiobacillus. J. Gen. Microbiol. 70:555-566.

54. Woese, C. R., O. Kandler, and M. L. Wheelis. 1990. Towards a natural system of organisms: proposal for the domains Archaea, Bacteria, and Eucarya. Proc. Natl. Acad. Sci. USA 87:4576-4579.

55. Zillig, W., S. Yeats, I. Holz, A. Bock, F. Gropp, M. Rettenberger, and S. Lutz. 1985. Plasmid-related anaerobic autotrophy of the novel archaebacterium Sulfolobus ambivalens. Nature (London) 313:789-791.

56. Zillig, W., S. Yeats, I. Holz, A. Bock, M. Rettenberger, F. Gropp, and G. Simon. 1986. Desulfurolobus ambivalens, gen. nov., sp. nov., an autotrophic archaebacterium facultatively oxidizing or reducing sulfur. Syst. Appl. Microbiol. 8:197-203. 